\title{
INTERGENERATIONAL JUSTICE AS INTERGENERATIONAL INCLUSION: NEW CHALLENGES FOR WELFARE SYSTEMS
}

\author{
ANNA ROSA FAVRETTO ${ }^{1}$ \\ GIACOMO BALDUZZI ${ }^{2}$
}

\begin{abstract}
The principle of intergenerational justice is much more common in the environmental sector, but it is becoming less unusual to consider it in a social and political context. The last economic crisis has significantly increased inequality among and across generations. In several EU countries, the number of NEETs raised dramatically after the recession. Moving from the Italian case, the paper focuses on the policies recently implemented to tackle the problem. Evidence shows that solutions exclusively focused on the labour market are not sufficient to activate a full social inclusion. Hence, the authors suggest considering intergenerational justice as intergenerational inclusion and in terms of active participation and empowerment in people's local communities. The analysis takes into account theoretical issues and practical implications of such a viewpoint, referring in particular to welfare systems and their effectiveness in facing this kind of challenge.
\end{abstract}

KEYWORDS: Intergenerational Justice; Labour Market Policy; Neets; Social Inclusion; Welfare Systems

\footnotetext{
${ }^{1}$ Full professor of Sociology; chief of Lab-SIA (CEIMS - Lab Health Childhood Adolescence); chief of Degree in Society and Local Development; member appointed by the University of Eastern Piedmont at the Permanent Regional Observatory against Bullying; member of the research group "NEOH", Network for Evaluation of One Health (Programme EU COST); member of editorial boards of scientific journals and Scientific Associations; principal investigator of many researches. Degrees: Ph.D. in Sociology (Catholic University of Milan); M.A. in Philosophy (University of Turin).

${ }^{2}$ Post-doc research fellow at University of Pavia, Temporary Lecturer in Sociology of collective choices at University of Eastern Piedmont, member of the research group "NEOH", Network for Evaluation of One Health (Programme EU COST), researcher at CIRSIS, Centre for Studies and Research on Higher Education Systems. Degrees: Ph.D. in "Institutions, Administration s and Regional Policies" (IAPR), University of Pavia; M.A. in Sociology, Catholic University of Milan.
} 


\section{INTRODUCTION}

This article refers to 'intergenerational justice' as that particular social area concerning the relations between present and future generations ${ }^{3}$. The idea that older generations have an ethical responsibility towards younger and future generations is not new. Nevertheless, recent emergent reflections on intergenerational justice have increasingly involved - in addition to the still current and fundamental ethical-philosophical field - political and social studies, lately also entering the juridical field ${ }^{4}$. From a sociological and an empirical point of view, we cannot use the concept of generation with analytic ease ${ }^{5}$. However, "The concept of generation thus serves as the crucial link between time and social structure and is important in understanding the progress of historical events and the course of social change" ${ }^{\prime \prime}$. In this article, we are interested in exploring the generational dimension of social inequality, especially from the perspective of labour market policies. Therefore, the article draws on an analysis of economic crisis impact on youth employment market in Italy. Subsequently, the investigation will address the labour market policies and their effects, also critically highlighting negative and paradoxical consequences. Empirical evidence from this study confirms the importance of an intergenerational justice perspective, in order to deal with the issues of the allocation of primary resources between different generations. Clearly, the development of policies ensuring a more equitable distribution of resources between present and future generations requires a view on what intergenerational justice is and how it can be effective within societies. The findings of this study suggest that the generational justice approach need to go beyond the completion for allocation of resources between elders and youngsters to embrace a view where cooperation and solidarity linkages are also important. Active

\footnotetext{
${ }^{3}$ See Simon Caney, 'Justice and Future Generations', Annual Review of Political Science, 21, 2018, pp. 475-493; Caney, 2018; Gemma M. Carney, Thomas Scharf, Virpi Timonen and Catherine Conlon $\mathrm{C}$, 'Blessed are the young, for they shall inherit the national debt: Solidarity between generations in the Irish crisis', Critical Social Policy 34, 3, 2014, pp. 312-332; Jörg Tremmel, A Theory of Intergenerational Justice. London, Routledge, 2009. Already in the nineteenth century, Thomas Jefferson calls national debts a problem of intergenerational ethics: Thomas Jefferson, 'Thomas Jefferson to John Wayles Eppes', 24 June 1813, National Archives (https://founders.archives.gov/documents/Jefferson/03-06-02-0200, accessed 11 April 2019).

${ }^{4}$ Leonardo Di Carlo, 'Il debito pubblico tra giustizia intergenerazionale, principio di proporzionalità e diritti di autonomia', Le istituzioni del federalismo, 29, 1, 2018, pp. 105-128.

${ }^{5}$ Gemma M. Carney, Thomas Scharf, Virpi Timonen and Catherine Conlon C, 'Blessed are the young, for they shall inherit the national debt: Solidarity between generations in the Irish crisis', Critical Social Policy, 2014, 34, 3, 2014, pp. 312-332. See also: Mannheim Karl 'The Problem of Generations', in Melissa A. Hardy (ed.), Studying Aging and Social Change: Conceptual and Methodological Issues, London, SAGE, 1993, pp. 22-65.

${ }^{6}$ Vern L. Bengtson Michael J. Furlong Robert S. Laufer, 'Time, Aging, and the Continuity of Social Structure: Themes and Issues in Generational Analysis', Journal of Social Issues, 39, 4, 1983, pp. 4571.
} 
measures policies or incentive packages dedicated to young people can partly help in reducing youth unemployment rates, as we will see in more detail below analysing the case of the Youth Guarantee program in Italy. However, these policies do not quite effectively tackle disparities in labour market. On the contrary, according to the findings of the present study, labour policies in some cases can also reproduce social inequalities. Practical learning coming from a pilot-project experimented in Novara (North-West Italy) indicate that the engagement in local community can provide fruitful results in terms of social and intergenerational inclusion. A possible policy change strategy, therefore, could focus on solutions that combine active labour market measures and actions promoting cooperation, social inclusion and active engagement of young people in their local community.

\section{THEORETICAL AND METHODOLOGICAL CONSIDERATIONS}

Although the concept of intergenerational justice is semantically dense and differently perceived across the literature, over the last few decades it has undoubtedly become a widespread theoretical framework, informing analyses and institutions' strategies.

Taking into consideration the huge international debate on the subject, two critical points appear relevant, according to the current study's objectives. The first concerns the prevalent focus of reflections on environmental issues. Since its initial steps, the global ecology movement has emphasised the vulnerability of future generations, whose survival relies on actions taken by - and thus lies in the hands of - current generations. Hence, new forms of sustainable development, as well as practices of renewable consumption, rest on the ethical imperative of equity between generations". As De-Shalit suggests, "the most important element in the question of intergenerational justice is the environmental issue, to which almost every aspect of intergenerational justice is related" 8 .

From the point of view of this paper, an exclusive focus on environmental issues may contribute to weakening attention on this idea, whose strength is useful for analysing not only ecology, but also other social and political fields. Ethically and politically unacceptable effects of generational differences in access to resources are evident in several areas of the collective life. Over the last economic crisis, for

\footnotetext{
${ }_{7}$ On this point, see the first definition of sustainable development proposed by the so-called Bruntland Report: World Commission on Environment and Development, Our Common Future, Oxford, Oxford University Press, 1987. A detailed discussion on ethical principles and legal instruments for the global environmental change, among many others, is in Edith Brown Weiss, 'Intergenerational equity: a legal framework for global environmental change', in Edith Brown Weiss (ed.) Environmental change and international law: New challenges and dimensions, Tokyo, United Nations University Press, 1992, pp. 385-412

${ }^{8}$ Avner de-Shalit, Why Posterity Matters: Environmental Policies and Future Generations, London-New York, Routledge, 1995, p. 7.
} 
example, labour market inequalities among and across generations in many countries has significantly increased, as we will see in what follows.

The second critical point we will take into consideration concerns whom the category termed 'future generations' includes. As Caney illustrates, the concept may have three different meanings: 1) those who are not yet born; 2) people who are not yet citizens (a group which, unlike the previous one, includes children); or 3) all generations, according to any age cohort, that follows it (which might include children and adult citizens, as well as the unborn) ${ }^{9}$. Clearly, if we adopt definitions 2 ) or 3), we admit that the principles of intergenerational justice do not refer exclusively to decisions between groups of people who are not presently alive, including overlapping generations as well ${ }^{10}$.

Some scholars stress the necessity of limiting the boundary of the intergenerational justice principle to relations between present and unborn generations. Menga, for example, claims an "ethical supremacy of otherness" in order to deal with the urgency, as well as difficulty, of relating to the foundation of obligations that are future-oriented ${ }^{11}$. Other scholars such as Gardiner (2009) argue that the intergenerational problem is a particular collective action issue, because earlier generations can improve the position of later generations - but no degree of effort by the latter can improve the situation of the former ${ }^{12}$. This view rejects relationships between contemporaries, in order to keep future generations away from any sort of contract theory, which is inadequate for dealing with intergenerational problems. On the other hand, other views support the notion that justice considerations between non-overlapping generations can be relevant in relations between contemporaries. In this regard, for example, Barry writes that we should start with our best understanding about the present in asking ethical questions concerning the future ${ }^{13}$.

Despite critical observations ${ }^{14}$, we consider this second option the most fruitful, for at least two reasons. Firstly, this approach opens up the possibility of handling the effects of generational distributive inequities, which currently affect both present and future generations. Secondly, it permits enlarging the analysis by

\footnotetext{
9 Simon Caney, 'Justice and Future Generations', Annual Review of Political Science, 21, 2018, p. 476.

${ }^{10}$ In Tremmel's terms, we can distinguish between the 'chronological-temporal' definition of the term generation on one side and the 'chronological-intertemporal' definition, on the other: Jörg Tremmel, A Theory of Intergenerational Justice. London, Routledge, 2009, pp. 19-25.

${ }^{11}$ Ferdinando G. Menga, 'Cose dell' "altro mondo". L'atopia della giustizia intergenerazionale quale sfida all'etica, alla politica e al diritto', Sociologia del diritto, 3, 2017, p. 43.

${ }^{12}$ Stephen M. Gardiner 'A contract on future generations?', in Axel Gosseries and Lukas H. Meyer (eds.) Intergenerational justice, Oxford, Oxford University Press, 2009, pp. 77-118.

${ }^{13}$ Brian Barry 'Sustainability and intergenerational justice', in Andrew Dobson (ed.), Fairness and Futurity: Essays on Environmental Sustainability and Social Justice, Oxford, UK, Oxford University Press, 1999, pp. 93-117.

${ }^{14}$ Ferdinando G. Menga, Lo scandalo del futuro. Per una giustizia intergenerazionale, Rome, Edizioni di Storia e Letteratura, 2017.
} 
incorporating significant variables for understanding inequalities in access to resources - such as, for example, social class, gender, education, locality, ethnicity, and so on.

The expansion of the analysis also makes it possible to observe that each generation is not homogeneous, due to the strong inequalities in intragenerational distribution of resources. As well, inequality is often greater in certain domains while, elsewhere, public or private remedies could reduce it.

Therefore, rather than making an abstract opposition between one generation and another, it is fruitful to consider that "generational structures" and "generational orders" are present in every civil context. Indeed, in modern societies, generations have increasingly assumed structural elements ${ }^{15}$. Consequently, they regulate how their social, cultural and economic relationships take shape, including the allocation of resources depending on the group to which a single individual belongs.

The approach introduced above makes it possible to consider a further social process concerning future generations. As historical evidence clearly shows, it is highly probable that inequalities, both among and across future generations, will have their origins in the present ones. In Barry's words, "some things that would be wrong in relation to the people in future (e.g. fighting a nuclear war) would in the first instance be wrong among those alive at the time" ${ }^{\prime 16}$. According to Peugny and Van de Velde, "inequality between generations is part of a wider generational chain, including past, present, and also future generations" ${ }^{\prime 1}$.

The idea of a generational chain paves the way for an examination of means of access to a professional occupation. This is a relevant subject, as it is associated with the satisfaction of primary needs of present and future generations, as well as their social inclusion. The important social and demographic variables mentioned above have longitudinal effects on the labour market, with consequent unequal distribution of resources across generations. In addition, in the labour market, a complex web of cultural, social and political choices produce a 'generational structure' - which also includes the models and practices for the distribution of

${ }^{15}$ Jens Qvortrup J, 'Childhood Matters: An Introduction', in Jens Qvortrup, Marjatta Bardy, Giovanni Sgritta, Helmut Wintersberger (eds.), Childhood Matters: Social Theory, Practice and Politics, Aldershot, Avebury Press, 1994, pp. 1-23; Leena Alanen, 'L'infanzia come concetto generazionale', in Heinz Hengst e Helga Zeiher (eds.), Per una sociologia dell' infanzia, Milano: FrancoAngeli pp. 5975; Leena Alanen, 'Generational Order', in Jens Qvortrup, William A. Corsaro, Michael-sebastian Honig (eds.), The Palgrave Handbook of Childhood Studies. London, Palgrave, 2009, pp. 159-174.

${ }^{16}$ Brian Barry 'Sustainability and intergenerational justice', Theoria: A Journal of Social and Political Theory, 89, 1999, pp. 59-60.

${ }_{17}$ Camille Peugny and Cécile Van de Velde, 'Repenser les inégalités entre générations', Revue française de sociologie, 54, 4, 2013, pp. 641-662. English version 'Rethinking Inter-Generational Inequality', translated by Peter Hamilton (https://www.cairn-int.info, accessed 23 April 2019). The idea of a 'chain of generations' is one of the key elements in Rawls's entire theory of justice: John Rawls, A Theory of Justice. Revised Edition, Cambridge, MA, Harvard University Press, 1999, p. 111. 
resources among the generations expressed and legitimised by society. The interdependence between past, present and future with respect to the effectiveness of the principles of intergenerational justice in the field of work imposes, finally, a reflection on the importance of building inter and intragenerational social ties as a means of mitigating inequalities.

The following two sections will present the case of the Italian labour market, with a particular focus on young people who are not in education, employment or training. The research includes both qualitative and quantitative analysis. As studies on young Italians' family backgrounds demonstrate ${ }^{18}$, lack of work and education are conditions that encourage the persistence of exclusion among the excluded, encompassing both children and subsequent generations. As we will see below, even the country's employment policies can incorporate somewhat generational reproduction of inequalities. However, there are projects that do not facilitate access to work within a short-term perspective. Among these, for example - as we will later briefly describe - the project CivicNEET in Novara aimed to help young people acquire social skills. Through experiences of civic engagement, alongside the formal internship, they established new inter and intragenerational social ties and generated useful goods for the community, thereby achieving cooperation among local actors.

\section{INTERGENERATIONAL INEQUALITIES AND NEETS: THE ITALIAN CASE}

In the past decade, the recession hit the Italian economy twice. The country suffered a first downturn in 2009 and a second crisis in 2012. As Figure 1 shows, Italy's GDP is still below the pre-crisis level, while the EU average has grown by over 10 points. The financial downturn affected Italy at a time of protracted structural weakness, after two decades of sluggish productivity growth and a high ratio of public debt to the gross domestic product (GDP) ${ }^{19}$.

According to recent estimates from the research department of Confindustria, the main association representing manufacturing and service companies in Italy, the country's economy is going to be stagnant for 2019, and then it will slightly improve during $2020,+0.4 \%$.

\footnotetext{
${ }^{18}$ E.g. Sara Alfieri, Emiliano Sironi, Elena Marta, Alessandro Rosina, and Daniela Marzana, 'Young Italian NEETs (Not in Employment, Education, or Training) and the Influence of Their Family Background', Europe's Journal of Psychology, 11, 2, 2015, pp. 311-322.

19 Eurostat, 'GDP and main components: output, expenditure and income', 2019a (http://appsso.eurostat.ec.europa.eu accessed 23 April 2019).

20 Centro Studi Confindustria, Dove va l'economia Italiana e gli scenari geoeconomici. Rome, Confindustria Servizi, 2019, p. 7.
} 
Figure 1. GDP Index in EU (28 countries) and Italy 2008-2018

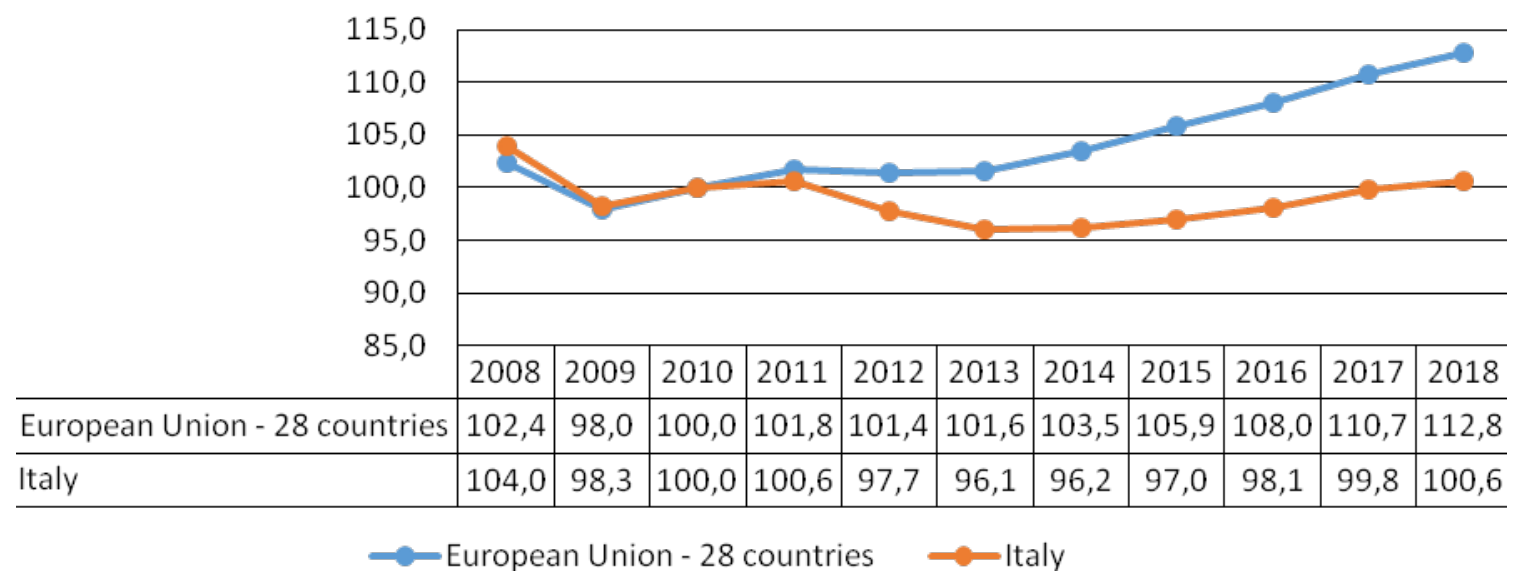

Source: Authors' elaboration from Eurostat.

The recession has had a strong impact on the labour market. The economy's capacity to provide jobs worsened and many jobs were lost. Between 2008 and 2013, 1,829 million annual work units, abbreviated as AWU, disappeared. Over the period 2014-2018, as the economic system started slowly to grow again, employment rates also increased and 792 million AWU went back to work. Nevertheless, full time workers are still 900 thousand less than ten years earlier, before the financial crash, while part-time workers, especially the involuntary ones, have increased ${ }^{21}$.

In Italy, as in other Southern Europe countries, the economic crises and 'selective flexibilisation' of the labour market produced growing inequalities between generations ${ }^{22}$. As stated in a recent report of European Commission, in Italy 'employment growth was supported by labour market reforms and hiring incentives, but was largely driven by temporary contracts, while still high levels of long-term and youth unemployment weigh on future economic growth prospects' (European Commission, 2018a: 8). According to Eurostat, in July 2018, the Italian youth unemployment rate was more than twice the EU average $(30.8 \% \text { vs } 14.8 \%)^{23}$.

The youth unemployment rate in Italy grew significantly further in the decade 2008-2018. In this country, additionally, intergenerational inequalities and regional

${ }^{21}$ Ministero del Lavoro, Istat, Inps, Inail and Anpal, Il mercato del lavoro 2018. Verso una lettura integrata. Rome, Istituto Nazionale di Statistica, 2019, p. 12.

22 Hans-Peter Blossfeld, Sandra Buchholz, Dirk Hofäcker and Sonia Bertolini, 'Selective flexibilization and deregulation of the labour market. The answer of Continental and Southern Europe', Stato e mercato 32(3), pp. 363-390; Francesco Fratto, 'Identifying Policy Innovations Increasing Labour Market Resilience and Inclusion of Vulnerable Groups. National Report Italy', Inspires Working Papers, 23, 2013, p. 10.

23 Eurostat 'News release euro indicators', 2018, 135/31-08-2018 (https://ec.europa.eu/eurostat/documents/2995521/9105310/3-31082018-AP-EN.pdf/772f244974be-415d-b4b0-351f31982720, accessed 23 April 2019). 
disparities have converged. As the figure illustrates below, youth unemployment has grown everywhere in the national territory; however, the phenomenon is significantly higher in the Southern regions compared to the rest of the country. Whereas, in the southern regions, one young person out of two is out of work, the proportion declines to one-fourth or even one-fifth in other parts of the country ${ }^{24}$.

In this connection, an emerging phenomenon in European countries, which looks particularly strong in Italy, is that of NEETs, an acronym for Not in Employment, Education, or Training - in short, young people who are unemployed or are outside the system of education and training. Critical researchers started to use the term 'NEET' with the publication of the UK Government's Bridging the Gap report in 199925; thus the acronym rapidly spread internationally and became widely used in media and political discourses after the global crisis of $2008^{26}$.

The negative effect of the crisis on labour markets, especially the youth labour market, emerged across all European countries. Between 2008 and 2013, the youth employment rate dropped from $37.3 \%$ in 2008 to $32.1 \%$ in 2013 . Conversely, youth unemployment and long-term unemployment increased from 15.6\% in 2008 to $23.7 \%$ in 2013 while, significantly, the rate of long-term unemployment among the unemployed youth population grew from $23 \%$ to $34 \%$ in the same period ${ }^{27}$. The NEET rate in Europe increased similarly, from $10.9 \%$ in 2009 to a peak of $13.2 \%$ in 2012. As the data mentioned above suggest, the recession exacerbated economic disparities between different generations across European countries. More pronounced increases in youth unemployment and in the NEET rates occurred in Mediterranean countries such as Spain and Italy ${ }^{28}$.

In 2017 , the proportion of young people not engaged in work or study in Italy was the highest among European Union member states ${ }^{29}$. More than a quarter

\footnotetext{
${ }^{24}$ Istat 'Rilevazione sulle forze lavoro. Tasso di disoccupazione giovanile totale. Italia e Regioni', Rome, Istituto Nazionale di Statistica, 2019a (http://noi-italia.istat.it, accessed 23 April 2019).

25 Social Exclusion Unit, Bridging the Gap: New Opportunities for 16-18 year olds not in education, employment or training, London, The Stationery Office, 1999.

${ }^{26}$ Valentina Cuzzocrea, 'Projecting the category of NEET into the future', in Council of Europe Directorate (ed.), Perspectives on Youth, Volume 1-2020 - what do you see?, Strasbourg, Council of Europe Publishing, 2014, pp. 69-82; Guido Cavalca, Young people in transitions: conditions, indicators and policy implications. To NEET or not to NEET?, in Gianluigi Coppola, Niall O'Higgins, (eds.), Youth and the Crisis. Unemployment, education and health in Europe, London-New York, Routledge, 2016, pp. 272-287.

27 Eurofound, Long-term unemployed youth: Characteristics and policy responses, Luxembourg, Publications Office of the European Union, 2017, p. 5.

${ }^{28}$ Francesca Salvà-Mut; Maria Tugores; Elena Quintana-Murci, 'NEETs in Spain: an analysis in a context of economic crisis', International Journal of Lifelong Education, 37, 2, 2018, pp. 168-183; Claudio Quintano; Paolo Mazzocchi; Antonella Rocca, 'The determinants of Italian NEETs and the effects of the economic crisis', Genus, 74, 5, 2018, pp. 1-24.

${ }^{29}$ Eurostat 'Young people neither in employment nor in education and training by sex, age and labour status (NEET rates)', 2019b (http://appsso.eurostat.ec.europa.eu, accessed 23 April 2019).
} 
(25.7\%) of young Italians aged between 18 and 24 years still were in this category, compared to an EU average of $14.3 \%$ and well behind the $5.3 \%$ of Holland and $8.6 \%$ of Germany.

Because of this evidence, use of the term 'NEET' became pervasive at the international level, with many international organisations and NGOs using it as a key indicator ${ }^{30}$. In particular, the European Commission (through the Europe 2020 initiative Youth on the Move), stated that it was 'a first priority' to provide pathways for NEETs 'to get back into education and training if needed or to bring them in contact with the labour market' ${ }^{\prime 31}$. The framework of Europe 2020 was the guideline informing policies and measures promoted by European institutions and instituted by national governments during the past years. The next section will deal with these policies and their effectiveness, with a glance toward single aspects of the Youth Guarantee Implementation in Italy.

\section{TACKLING GENERATIONAL AND SOCIAL INEQUALITIES: HOW ARE POLICIES WORKING?}

Youth Guarantee has been one of the most significant EU initiatives undertaken to address generational and social inequalities. This programme, drawing inspiration from the Scandinavian experience ${ }^{32}$, aims systematically to reach those young people who are not working or involved in education or training, providing them with integration programmes facilitating access to employment, education or vocational training.

In 2013, one year after the Commission's initial proposal, the Council adopted a Recommendation ensuring that all young people under 25 receive a good quality offer of employment, continued education or apprenticeship/traineeship within four months of leaving school or becoming unemployed ${ }^{33}$. In addition, the European Council established the Youth Employment Initiative with a budget of 6.4 billion euro, in order to increase EU support for regions and individuals struggling the most with youth unemployment and inactivity. The programme

\footnotetext{
${ }^{30}$ Valentina Cuzzocrea, 'Projecting the category of NEET into the future', in Council of Europe Directorate (ed.), Perspectives on Youth, Volume 1-2020 - what do you see?, Strasbourg, Council of Europe Publishing, 2014, pp. 69-82; Eurofound, NEETs. Young people not in employment, education or training: Characteristics, costs and policy responses in Europe, Luxembourg, Publications Office of the European Union, 2012.

${ }^{31}$ European Commission, Youth on the move. An initiative to unleash the potential of young people to achieve smart, sustainable and inclusive growth in the European Union, Luxembourg, Publications Office of the European Union, 2010, p. 16.

${ }^{32}$ Francesco Pastore, 'Why so slow? The school-to-work transition in Italy', Studies in Higher Education, 44, 8, 2019, pp. 1358-1371; Ibid., 'The European Youth Guarantee: Labor Market Context, Conditions and Opportunities in Italy', IZA Journal of European Labor Studies, 11, 4, 2015 (https://izajoels.springeropen.com/articles/10.1186/s40174-015-0033-2, accessed 19 April 2019).

${ }^{33}$ European Council, Council Recommendation of 22 April 2013 on establishing a Youth Guarantee, Luxembourg, 22.04.2013 (2013/C 120/01).
} 
allocated funding to the regions that have youth unemployment rates of more than 25\% in 2012 and to NUTS level 2 regions where the indicator was higher than $20 \%$ in 2012 in member states where young job seekers have increased by more than $30 \%$ in $2012^{34}$.

The Italian Government instituted a Youth Guarantee Implementation Plan on 23 December $2013^{35}$. Italy also was eligible for the Youth Employment Initiative. As of 28 February 2019, almost five years from the launch of the Youth Guarantee, NEETs registered in the programme's portal numbered 1,450,53936. After a slow start in 2014, implementation of the Youth Guarantee progressed significantly in the ensuing years ${ }^{37}$. Considering that 1,723,000 NEETs aged 15-29 available for work in 2013 constituted the target group ${ }^{38}$, the programme, according to data provided by the National Agency for Active Labour Policies:

- has involved over $84 \%$ of the target;

- has included 1,126,767 (65.39\%) with a first introductory meeting;

- $\quad$ has offered an active measure to $618,897(35.92 \%)^{39}$.

In the month after conclusion of the Youth Guarantee action, $44.6 \%$ of those served found their first job - a number that rises to $52.8 \%$ if we consider a long period of time (within six months). Further, 36.8\% of young people entered the labour market with an apprenticeship contract, $20.1 \%$ did so with a fixed term contract and $39.5 \%$ with an open-ended contract.

In Italy, regional governments manage the labour market policies. Thus, implementation of Youth Guarantee differed from one region to another, for example, with respect to the role of public and private sectors in the provision of the service. Three models have emerged. The first is the 'voucher model' of Lombardy, Piedmont and Campania, where the young person has had the option

\footnotetext{
${ }^{34}$ European Commission, Guidance on implementing the Youth. Employment Initiative. European Social Fund thematic paper, Luxembourg, Publications Office of the European Union, 2014, p. 6.

${ }^{35}$ Governo della Repubblica Italiana, 'Italian Youth Guarantee Implementation Plan', Rome, 2013, report presented on 23 December 2013 (http://www.garanziagiovani.gov.it, accessed 23 April 2019).

${ }^{36}$ Anpal, 'Garanzia Giovani in Italia. Nota mensile', Agenzia Nazionale Politiche Attive del Lavoro, 2, 2019, p. 4 (https://www.anpal.gov.it/dati-e-pubblicazioni/note-brevi, accessed 23 April 2019).

${ }^{37}$ European Court of Auditors, Youth unemployment - have EU policies made a difference? An assessment of the Youth Guarantee and the Youth Employment Initiative, Luxembourg, Publications Office of the European Union, 2017, p. 29.

${ }^{38}$ European Court of Auditors, Youth unemployment - have EU policies made a difference? An assessment of the Youth Guarantee and the Youth Employment Initiative, Luxembourg, Publications Office of the European Union, 2017, p. 40.
}

${ }^{39}$ Anpal, 'Garanzia Giovani in Italia. Nota mensile', Agenzia Nazionale Politiche Attive del Lavoro, 2, 2019, pp. 4-7 (https://www.anpal.gov.it/dati-e-pubblicazioni/note-brevi, accessed 23 April 2019). 
of choosing entry into public service or the private sector. In this case, agencies could contact the potential users. The second is the 'project model' - adopted, for example, in Veneto and Apulia. Here private agencies supported the programme directly after the training phase, by helping young people in finding available job opportunities. Finally, regions such as Emilia-Romagna, Toscana and Friuli Venezia Giulia constitute the third model. Here policy makers use different procedures, giving priority to the public job centres. Altogether, public services took charge of the largest number of persons $(78.7 \%)$, compared to private enterprises $(21.3 \%)$. In the northwest regions, the opposite happened: private agencies played a crucial role, managing a higher proportion of registered people (78.3\%), with the remaining 21.7\% dedicated to public job centres (Anpal, 2019: 3).

Due to a more favourable macroeconomic context and some positive outcomes of the Youth Guarantee, the youth unemployment rate in Italy has seen a decrease in the last few years. However, this decline has been milder than that seen in other European countries: the number of NEETs has dropped from 2.41 million in 2014 to 2.11 million in $2018^{40}$. Moreover, as the evidence provided below points out, public and private agencies, in implementing the programme, have not fully tackled the social and territorial inequalities affecting young people of the country. Rather, the programme, in some ways, has reproduced such disparities. The data in Table 1 makes it clear that young people who are more vulnerable (high profile) have an employment rate significantly lower than that of peers with more advantageous background (low profile). Similarly, the employment rate of young people having participated in the programme is valuably higher in northwest regions than in southern ones. Further, the employment rate is slightly higher among male programme participants $(55.3 \%)$ than females $(50.1 \%)^{41}$.

Table 1. Employment rates 1 and 6 months after Youth Guarantee interventions by characteristics of beneficiaries (percentage points)

\begin{tabular}{|c|c|c|}
\hline & 1 month & 6 months \\
\hline Low profile & 64.3 & 71.8 \\
\hline High profile & 31.6 & 39.3 \\
\hline Northwest & 58.1 & 66.2 \\
\hline South and Islands & 30.8 & 38.5 \\
\hline
\end{tabular}

Source: Anpal

${ }^{40}$ Istat (2019b) 'Rilevazione sulle forze lavoro. NEET (giovani non occupati e non in istruzione e formazione)', Rome, Istituto Nazionale di Statistica, 2019b (http://dati.istat.it, accessed 23 April 2019).

${ }^{41}$ Anpal, 'Garanzia Giovani in Italia. Nota mensile', Agenzia Nazionale Politiche Attive del Lavoro, 2, 2019, p. 7 (https://www.anpal.gov.it/dati-e-pubblicazioni/note-brevi, accessed 23 April 2019). 
From another standpoint, qualitative data collected from the field contribute to understanding how some labour market mechanisms reproduce social inequalities and class differences. In particular, poorer young people from working-class families generally accept all kinds of jobs - including positions that are underpaid and unsuitable to their experience and skills. Conversely, richer young people from upper classes typically refused job offers considered too modest or underqualified, instead waiting for ones that provided a better social status. Being aware of this reality, employment agencies tend to present the less qualifying and rewarding job offers to those people who are more likely to accept them. Such considerations suggest the need for forms of social integration more extensive and fundamental than internships and other measures provided by Youth Guarantee.

In order to contrast the 'multi-faceted barriers' 42 and deal with the social, cultural, economic and educational disparities hiding behind NEETs and youth unemployment, it is necessary to combine active labour market policies with medium and long-term institutional strategies. It may be particularly important, based on the data reported above, to consider the social and territorial context of the young people they address. In this sense, it could be useful, on the one hand, to enforce the ability of the single person to activate networks and skills and, on the other, to push different actors to cooperate and invest their resources into a shared direction of inclusion, in order to generate a 'systemic' response to the problem.

The pilot project CivicNEET, realised in the Province of Novara, in Piedmont (north-west Italy) between 2016 and 2018, followed such a dual intent ${ }^{43}$. Funded by the Cariplo Foundation, the initiative started with the active support of a pool of regional institutions, universities, non-profit organisations and local employers' associations within the Youth Guarantee framework. Programme participants were secondary school graduates working as trainees in manufacturing firms. The project offered a select group of young people involved in the Youth Guarantee programme the opportunity of conducting a 'community project', that is, an experience of civic engagement alongside the formal internship. All such 'community projects' aimed at involving the participants in new social networks in order to allow them to gain new social and professional skills. Many young participants, given new and expanded job or study options, have revised their life aspirations. The project provided young participants opportunities to develop

${ }^{42}$ Oecd, Job Creation and Local Economic Development, Paris, Oecd Publishing, 2014, p. 87.

${ }^{43}$ Eliana Baici, Davide Servetti, Carmen Aina, Giacomo Balduzzi, Giorgia Casalone, Michele Rostan, 'Non solo stage: lavoro, inclusione e progetti di comunità in una sperimentazione a Novara', in $S$ Alfieri, E Sironi (eds.), Una generazione in panchina. Da NEET a risorsa per il Paese, Milano, Vita e pensiero, 2017, pp. 315-329; Michele Fontefrancesco and Giacomo Balduzzi, 'NEET What?, NEET Where? Empirical evidences and reflections from Novara (Italy)', Paper presented at 14th EASA Conference Anthropological legacies and human futures. Milan, July 20-23, 2016; Giuseppe Terzo, 'Il Terzo settore come driver delle politiche di attivazione dei giovani NEET in un'ottica di 'secondo welfare'. Alcune riflessioni a margine dell'iniziativa Youth Guarantee', Paper presented at XII Colloquio scientifico sull'impresa sociale, Trento, May 25, 2018. 
inclinations and talents, with the possibility of further enhancing them in their education and in the initial phase of job introduction.

Only young men have accepted to participate to the project; such a gender effect was stronger than expected. Even considering that the Italian manufacturing sector predominantly employs male workers ${ }^{44}$, it is important to note that young women interviewed during the search for candidates expressed conflicts around dedicating themselves to community projects that extended outside regular working hours, due to existing family commitments. In future applications, it will be necessary to identify appropriate methods of inclusion and dedicated incentives, as a means of overcoming such barriers (which still being very strong can hinder participation of young women in the collective life of the greater society).

CivicNEET suggests the importance of strengthening social relations and intergenerational linkages. For young Italians, participation in the 'community project' became a way to increase dialogue and cooperation with peers and older people. Evidence from in-depth interviews indicates that participation to community projects has been an incentive for young participants to overcome isolation and the sense of shame, as can attend the experience of unemployment; it has created linkages between generations, which otherwise likely would not have occurred ${ }^{45}$. In addition, the project had important consequences in terms of mobilisation of local institutions and development of a 'place-based approach' to youth inclusion policies. This approach thus integrates two policy objectives often addressed as separate and distinct issues: activation of the labour market and social inclusion of young people.

\section{CONCLUSION}

The case of inequalities in labour market is particularly challenging for welfare systems from the perspective of intergenerational justice as a policy and legal framework. As the Italian case underscores, present younger generations are 'inheriting' their relative disadvantaged conditions from the past; meanwhile, since inequalities are increasing, future unborn generations may have fewer opportunities to access work. Disparities may thus grow further as differences in social class, gender, age, education, geographical location and ethnicity increase. Empirical analysis in this field thus confirms the hypothesis that present, past and future generations link to each other as a whole chain.

By analysing the generational inequalities in the Italian labour market and recent attempts to mitigate it, this paper can conclude that an effective intergenerational justice policy is still missing in Italy. Inter and intragenerational inequalities strongly affect the labour market. While decreasing, young

${ }^{44}$ Istat, Annuario statistico italiano, Rome, Istituto Nazionale di Statistica, 2018, pp. 308-309.

${ }^{45}$ Giacomo Balduzzi carried out the fieldwork doing interviews and participant observations during the period during the period July 2016-September 2018. Other information and documents are available online on the project's website. https://www.civicneet.it. 
unemployed and NEETs remain a consistent problem, especially in the southern regions of the country. Youth Guarantee has generated a significant amount of active measures, contributing to matching the supply of work opportunities with their demand. Unfortunately, some evidence suggests that the European programme has been ineffective in tackling inequalities - and, in fact, in some cases has reproduced existing social disparities.

Useful elements in line with an effective intergenerational justice policy come from projects such as CivicNEET, which aim at enforcing networks and skills and generating inter and intragenerational cooperation as well as solidarity linkages at a community level. This appears to be a relevant point in the debate on intergenerational justice.

Merely increasing job opportunities is not sufficient if the aim is effectively rebalancing inequalities among and across generations in the labour market. Further, activating labour market policies are increasingly following the guiding principle of "help and hassle" 46 . Acting in a short-term logic, activating policies aim at a temporary reintegration into the labour market. Intending to prevent 'social dependency', they banish social inclusion.

We need an integrated approach, capable of activating both the labour market and the social inclusion of young people, within a longer-term, more comprehensive vision.

From this perspective, the intergenerational justice concept could help to expand single, compartmentalised subjects - such as spheres of work, housing, health, environment, and so on - into a wider political and social framework, able to regard the current world from the viewpoint of future generations. In this respect, we can conceive the principle of intergenerational justice as intergenerational inclusion. Fully active participation of all generations in social life introduces the possibility of tying together the generational chain and planning a sustainable future, which starts - firstly and foremost - from the present.

Welfare systems can rise to the challenge of promoting justice between generations. However, to do this they must return to looking at policies over the long run. Short-term policy cannot have an impact on the generational chain. Furthermore, intergenerational justice requires a more extensive social inclusion. Age groups cannot only compete for zero-sum resource allocation, but they must cooperate each other and negotiate new win-win strategies. As a result, it will be possible to develop new forms social inclusion, linking different generations in collective processes of institutional change, especially at a community and local level.

\section{REFERENCES}

\footnotetext{
${ }^{46}$ Markus Griesser, 'Images and imaginaries of unemployed people: Discursive shifts in the transition from active to activating labour market policies in Germany', Critical Social Policy, 38, 2, 2018, pp. 387-406.
} 
Alanen L (2004) ‘L'infanzia come concetto generazionale', pp. 59-75 in H Hengst, H Zeiher (eds) Per una sociologia dell'infanzia. Milano: FrancoAngeli.

Alanen L (2009) 'Generational Order', pp. 159-174 in J Qvortrup, WA Corsaro, MS Honig (eds) The Palgrave Handbook of Childhood Studies. London: Palgrave.

Alfieri S, Sironi E, Marta E, Rosina A and Marzana D (2015) 'Young Italian NEETs (Not in Employment, Education, or Training) and the Influence of Their Family Background', Europe's Journal of Psychology 11(2): 311-322.

Anpal (2019) 'Garanzia Giovani in Italia. Nota mensile', Agenzia Nazionale Politiche Attive del Lavoro 2019/2 [https://www.anpal.gov.it/dati-epubblicazioni/note-brevi], accessed 23 April 2019.

Baici E, Servetti D, Aina C, Balduzzi G, Casalone G and Rostan M (2017) `Non solo stage: lavoro, inclusione e progetti di comunità in una sperimentazione a Novara', pp. 315-329 in S Alfieri, E Sironi (eds) Una generazione in panchina. Da NEET a risorsa per il Paese. Milano: Vita e pensiero.

Barry B (1999a) 'Sustainability and intergenerational justice', pp. 93-117 in A Dobson (ed) Fairness and Futurity: Essays on Environmental Sustainability and Social Justice. Oxford, UK: Oxford University Press.

Barry B (1999b) 'Sustainability and intergenerational justice', Theoria: A Journal of Social and Political Theory, 89: 43-64.

Bengtson V, Furlong M and Laufer R (1983) 'Time, Aging, and the Continuity of Social Structure: Themes and Issues in Generational Analysis', Journal of Social Issues 39(4): 45-71.

Blossfeld HP, Buchholz S, Hofäcker D and Bertolini S (2012) 'Selective flexibilization and deregulation of the labour market. The answer of Continental and Southern Europe', Stato e mercato 32(3): 363-390.

Brown-Weiss E (1992) 'Intergenerational equity: a legal framework for global environmental change', pp. 385-412 in E Brown-Weiss (ed) Environmental change and international law: New challenges and dimensions. Tokyo: United Nations University Press.

Caney S (2018) 'Justice and Future Generations', Annual Review of Political Science, 21: 475-493. 
Carney GM, Scharf T, Timonen V and Conlon C (2014) 'Blessed are the young, for they shall inherit the national debt: Solidarity between generations in the Irish crisis', Critical Social Policy 34(3): 312-332.

Cavalca G (2016) 'Young people in transitions: conditions, indicators and policy implications. To NEET or not to NEET?', pp. 272-287 in G Coppola and N $\mathrm{O}^{\prime}$ Higgins (eds) Youth and the Crisis. Unemployment, education and health in Europe. London-New York: Routledge.

Centro Studi Confindustria (2019) Dove va l'economia Italiana e gli scenari geoeconomici. Rome: Confindustria Servizi.

Cuzzocrea V (2014) 'Projecting the category of NEET into the future', pp. 69-82 in Council of Europe Directorate (ed) Perspectives on Youth, Volume 1 - 2020 what do you see?. Strasbourg: Council of Europe Publishing.

De-Shalit A (1995) Why Posterity Matters. Environmental Policies and Future Generations. London-New York: Routledge.

Di Carlo LS (2018) ‘Il debito pubblico tra giustizia intergenerazionale, principio di proporzionalità e diritti di autonomia', Le istituzioni del federalismo 29(1): 105128.

Eurofound (2017) Long-term unemployed youth: Characteristics and policy responses. Luxembourg: Publications Office of the European Union.

Eurofound (2012) NEETs. Young people not in employment, education or training: Characteristics, costs and policy responses in Europe. Luxembourg: Publications Office of the European Union.

European Commission (2018a) Italy. Report prepared in accordance with Article 126(3) of the Treaty on the Functioning of the European Union. Brussels, 21.11.2018 COM (2018) 809 final.

European Commission (2018b) Youth Guarantee country by country. Italy. May 2018. Brussels: DG Employment, Social Affairs \& Inclusion.

European Commission (2014) Guidance on implementing the Youth. Employment Initiative. European Social Fund thematic paper. Luxembourg: Publications Office of the European Union. 
European Commission (2010). Youth on the move. An initiative to unleash the potential of young people to achieve smart, sustainable and inclusive growth in the European Union. Luxembourg: Publications Office of the European Union.

\section{European Council (2013), Council Recommendation of 22 April 2013 on} establishing a Youth Guarantee. Luxembourg, 22.04 .2013 (2013/C 120/01).

European Court of Auditors (2017) Youth unemployment - have EU policies made a difference? An assessment of the Youth Guarantee and the Youth Employment Initiative. Luxembourg: Publications Office of the European Union.

Eurostat (2018) 'News release euro indicators', 135/31-08-2018.

[https://ec.europa.eu/eurostat/documents/2995521/9105310/3-31082018-APEN.pdf/772f2449-74be-415d-b4b0-351f31982720] accessed 23 April 2019.

Eurostat (2019a) 'GDP and main components (output, expenditure and income)' [http://appsso.eurostat.ec.europa.eu] accessed 23 April 2019.

Eurostat (2019b) 'Young people neither in employment nor in education and training by sex, age and labour status (NEET rates)'

[http://appsso.eurostat.ec.europa.eu] accessed 23 April 2019.

Fontefrancesco MF and Balduzzi G (2016), 'NEET What?, NEET Where? Empirical evidences and reflections from Novara (Italy)', Paper presented at $14^{\text {th }}$ EASA Conference Anthropological legacies and human futures. Milan, July 20-23, 2016.

Fratto F (2013) 'Identifying Policy Innovations Increasing Labour Market Resilience and Inclusion of Vulnerable Groups. National Report Italy', Inspires Working Papers 23.

Gardiner SM (2009) 'A contract on future generations?', pp. 77-118 in A Gosseries and LH Meyer (eds) Intergenerational justice. Oxford: Oxford University Press.

Governo della Repubblica Italiana (2013) ‘Italian Youth Guarantee Implementation Plan', report presented on 23 December 2013 [http://www.garanziagiovani.gov.it] accessed 23 April 2019.

Griesser M (2018) ‘Images and imaginaries of unemployed people: Discursive shifts in the transition from active to activating labour market policies in Germany', Critical Social Policy 38(2): 387-406. 
Istat (2018) Annuario statistico italiano 2018. Rome: Istituto Nazionale di Statistica.

Istat (2019a) ‘Rilevazione sulle forze lavoro. Tasso di disoccupazione giovanile totale. Italia e Regioni', Rome, Istituto Nazionale di Statistica [http://noiitalia.istat.it] accessed 23 April 2019.

Istat (2019b) 'Rilevazione sulle forze lavoro. NEET (giovani non occupati e non in istruzione e formazione)' ${ }^{\prime}$, Rome, Istituto Nazionale di Statistica [http://dati.istat.it] accessed 23 April 2019.

Jefferson T (1813) 'Thomas Jefferson to John Wayles Eppes', 24 June 1813, National Archives, [https://founders.archives.gov/documents/Jefferson/0306-02-0200] accessed 11 April 2019.

Lumer C (2006) 'Principles of Generational Justice', pp. 39-52 in JC Tremmel (ed.) Handbook of Intergenerational Justice. Cheltenham, UK-Northampton, MA, USA: Edward Elgar 2006.

Mannheim K (1993) 'The Problem of Generations', pp. 22-65 in MA Hardy (ed.) Studying Aging and Social Change: Conceptual and Methodological Issues. London: SAGE.

Menga F (2017a) 'Cose dell' “altro mondo". L'atopia della giustizia intergenerazionale quale sfida all' etica, alla politica e al diritto', Sociologia del diritto 3: 29-57.

Menga F (2017b) Lo scandalo del futuro. Per una giustizia intergenerazionale. Rome: Edizioni di Storia e Letteratura.

Ministero del Lavoro, Istat, Inps, Inail and Anpal (2019) Il mercato del lavoro 2018. Verso una lettura integrata. Rome: Istituto Nazionale di Statistica.

Oecd (2014) Job Creation and Local Economic Development. Paris: Oecd Publishing.

Pastore F (2019) 'Why so slow? The school-to-work transition in Italy', Studies in Higher Education DOI: 10.1080/03075079.2018.1437722.

Pastore F (2015) 'The European Youth Guarantee: Labor Market Context, Conditions and Opportunities in Italy', IZA Journal of European Labor Studies 11(4). 
Peugny C and Van de Velde C (2013) 'Repenser les inégalités entre générations', Revue française de sociologie 54(4): 641-662. English version 'Rethinking InterGenerational Inequality' translated by Peter Hamilton [https://www.cairnint.info] accessed 23 April 2019.

Quintano C, Mazzocchi P and Rocca A (2018) 'The determinants of Italian NEETs and the effects of the economic crisis', Genus 74(1) DOI: 10.1186/s41118-018-00310 .

Qvortrup J (1994) 'Childhood Matters: An Introduction', pp. 1-23 in J Qvortrup, M Bardy, Sgritta G and H Wintersberger (eds) Childhood Matters: Social Theory, Practice and Politics. Aldershot: Avebury Press.

Rawls J (1999) A Theory of Justice. Revised Edition. Cambridge, MA: Harvard University Press.

Salvà-Mut F, Tugores-Ques M and Quintana-Murci E (2018) 'NEETs in Spain: an analysis in a context of economic crisis', International Journal of Lifelong

Education 37(2): 168-183.

Social Exclusion Unit (1999) Bridging the Gap: New Opportunities for 16-18year-olds not in education, employment or training. London: The Stationery Office.

Terzo G (2018) 'Il Terzo settore come driver delle politiche di attivazione dei giovani NEET in un'ottica di 'secondo welfare'. Alcune riflessioni a margine dell'iniziativa Youth Guarantee', Paper presented at XII Colloquio scientifico sull'impresa sociale. Trento, May 25, 2018.

Tremmel J C (2009) A Theory of Intergenerational Justice. London: Routledge.

World Commission on Environment and Development (1987) Our Common

Future. Oxford: Oxford University Press. 